\title{
Farming and feasting in the Neolithic of Greece: the ecological context of fighting with food
}

\author{
Paul Halstead \\ Department of Archaeology, University of Sheffield, UK \\ p.halstead@sheffield.ac.uk
}

\begin{abstract}
Fine Neolithic ceramics from Greece are widely interpreted in terms of ceremonial eating and drinking, while the spatial organisation of settlement suggests that such commensality played a significant role in shaping social relationships. Faunal evidence implies consumption of many domestic animals in large-scale commensality and supports the view that this promoted competition as well as solidarity. This paper explores the ecological context of such 'fighting with food'. Feasting, and ceremonial consumption of livestock, was enabled by and helped to reinforce domestic strategies of surplus production and labour mobilisation that were driven as much by 'economic' as 'political' imperatives.
\end{abstract}

IZVLEČEK - Fino neolitsko grško keramiko ponavadi povezujejo s ceremonialnim uživanjem hrane in pijače, prostorska organiziranost naselbin pa kaže, da so bili skupni obedi zelo pomembni pri oblikovanju družbenih odnosov. Po živalskih ostankih lahko sklepamo, da so uživali številne domače živali na velikih pojedinah, kar naj bi pospeševalo tekmovalnost pa tudi solidarnost. V̌̌lanku raziščemo ekološke vidike 'tekmovanja s hrano'. Gostije in ceremonialno uživanje živali je bilo možno zaradi načrtovanja viškov proizvodnje in organiziranega dela in ju hkrati utrjevalo. Motiv za to pa je bil tako 'gospodarski' kot 'politični'.

KEY WORDS - Neolithic; Greece; feasting; domestic animals; overproduction

\section{INTRODUCTION}

A concern with feasting is currently fashionable in the archaeology of various periods and regions, but there are solid empirical grounds for emphasising this topic with respect to the Neolithic of southeast Europe. First, fine and sometimes elaborately decorated ceramic vessels, in shapes suitable for serving or consuming food and drink and perhaps other stimulants, indicate that Neolithic societies accorded considerable cultural significance to at least some acts of consumption (e.g., Vitelli 1989; Pappa at al. in press). And, as Sherratt (1991) has noted, the provision of some fine vessels with flat bases may literally indicate their use as 'tableware', thus further underlining the importance of certain consumption events. Secondly, the broad distribution of many ceramic styles (e.g., Washburn 1983) and growing evidence that at least some fine vessels were ex- changed over considerable distances (e.g., Tomkins, Day 2001; Hitsiou 2003) imply that ceremonial consumption may have played an important role in social interaction on a supra-local as well as local scale.

Moreover, while many forms of exchange may serve to initiate or maintain amicable social relationships (Mauss 1970), the giving and receiving of food and drink are widely regarded as symbolising particularly close and binding social relationships (e.g., $R i$ chards 1939; Sahlins 1974.215-219). The archaeological record from the Neolithic of Greece provides circumstantial clues to some of the social contexts in which commensality is likely to have played an important role. First, despite legitimate cautioning against the simple equation of Neolithic with sedentary (e.g., Whittle 1997), the available bioarchaeolo- 
gical evidence suggests that many or even most known Neolithic sites in Greece were occupied on a more or less year-round basis (Halstead in press). The evident long-term continuity of many such sedentary communities implies mechanisms for resolving or counteracting the inevitable tensions between neighbours that are often defused through fission in a more mobile population. Moreover, the gradual development of many Neolithic settlements into long-lived 'tells' is accompanied by increasing architectural segregation of constituent 'households' or 'neighbourhoods' (Hourmouziadis 1979; Theochares 1980; Kotsakis 1982; Halstead 1995) and indeed it has been argued persuasively that these two processes are causally related (Kotsakis 1999). At an intra-settlement level, commensality between neighbours is likely to have played a central role in promoting community solidarity in the face of these inevitable tensions and tendencies to residential segregation. Secondly, at least in Thessaly, some longlived sites were located sufficiently close together (e.g., Perlès 1999) to imply significant investment in the maintenance of peaceful relations and avoidance of the endemic warfare characteristic of recent horticultural villages in parts of New Guinea (Forge 1972; Brown 1978) and South America (Chagnon 1968). At this inter-settlement level, commensality may again have served to affirm such peaceful relations.

On the other hand, the example of highland New Guinea underlines how feasts may be an important arena not only for alliance building, but also for competition both within and between communities (also Dietler 2001.72). Such competitive commensality may be reflected in the recent discovery at LN Makriyalos in Central Macedonia of the remains of what seems to be a short-lived episode or phase of consumption, involving the slaughter of hundreds (probably thousands) of domestic animals (Pappa et al. in press). The implied consumption of many tons of meat over a period of several months suggests participation on at least a community-wide and perhaps regional scale and raises the possibility of spectacular cycles of herd expansion and mass slaughter such as accompany pig feasts in parts of highland New Guinea (Rappaport 1968; Brown 1978; Wiessner 2001).

There are thus reasonable grounds for claiming that ceremonial commensality, probably on a range of social and temporal scales, played a major role in the Neolithic of Greece both in helping to shape the development of some distinctive forms of material culture and in negotiating vital but potentially contentious social relationships. Both these points have been made elsewhere (e.g., Vitelli 1989; Halstead 1995; Andreou et al. 1996). The present paper seeks to develop these themes and then to explore the ecological context of the relationship between feasting and early farming and, more particularly, the role therein of domestic animals. The discussion is cast in terms of the Neolithic of Greece, but could in large measure be extended to adjacent parts of southeast Europe and Anatolia, which share a broadly similar Neolithic archaeological record and broadly similar ecological conditions for early farming.

\section{FEASTING, COMMENSAL POLITICS AND FARMING}

Thus far, in asserting that feasting may have played a significant role in the Neolithic societies of Greece, it has been tacitly assumed that 'feasting' refers to 'ceremonial commensality'. Essentially similar definitions have been offered by Hayden - 'any sharing between two or more people of special foods (i.e., foods not generally served at daily meals) in a meal for a special purpose or occasion' (Hayden 2001a. 29) - and Dietler - 'public ritual activity centered around the communal consumption of food and drink' (Dietler 2001.67). In addition, Dietler has emphasised the political dimension of feasting or 'commensal politics' (Dietler 2001.73) and, as already indicated, this dimension is of central interest in the context of the Neolithic of Greece.

This emphasis on commensal politics highlights the importance of the distinction between host/ provider and guest/consumer (Hayden 2001a.44) and the fundamental enabling role of the provision of food and drink in abundance (Wiessner 2001.117). As Hayden observes, the opportunities for political manipulation of commensality are thus restricted among 'generalized' foragers (Hayden 2001a.4445): an ethos of collective rights to consumption downplays the distinction between host/ provider and guest/consumer (Barnard, Woodburn 1991; Ingold 1983; Kent 1993), while scope for the provision of abundance is modest in the absence of both food production and large-scale storage. Conversely, food production and large-scale storage greatly facilitate the provision of abundance and, in turn, are predicated on significant circumscription of collective rights to consumption. Indeed, Ingold has argued that the most fundamental difference between a wild animal and its domestic counterpart is that the latter belongs to some person(s) (Ingold 1986. 
113). Among generalized 'immediate-return' foragers, therefore, with an ethos of collective rights to consumption, the sharing out of a kill may earn prestige for the hunter; among hunters or farmers heavily dependent on storage, with more limited collective rights, the giving of food tends to leave the recipient indebted to the donor (Ingold 1980.172-176; Barnard, Woodburn 1991). This shift in the relationship between donor and recipient is crucial to commensal politics.

While a capacity for abundant provision may be more likely, and the distinction between host/provider and guest/consumer generally clearer, among farmers than generalized foragers, is there any evidence that Hayden's two suggested preconditions for dynamic commensal politics were met by the Neolithic communities of Greece? We may begin by considering the capacity for abundant provisioning of feasts in the Neolithic of Greece. Rare direct evidence for such a capacity is provided by the massive dump of animal remains at Makriyalos, referred to above, but circumstantial arguments suggest that periodic abundance may have been endemic to Neolithic communities in Greece. Bioarchaeological evidence from habitation sites in this region suggests that Neolithic subsistence was overwhelmingly dominated by cultivated grains and domestic animals, with only a modest contribution from gathered plants and hunted animals, but leaves open to debate the relative contribution of crops and livestock. Many of these sites, however, take the form of villages comprising numerous 'houses' and probably representing between several tens and a few hundreds of inhabitants; available bioarchaeological evidence for seasons of human presence favours year-round occupation. The combination of village settlement and year-round habitation strongly favours dependence on stored cereal and pulse grain crops rather than livestock as the basis of Neolithic subsistence (e.g., Halstead 1989a). The difficulty of detecting the impact of early farming in regional pollen records (Bottema 1982; also Willis, Bennett 1994) also makes extensive animal husbandry unlikely, while there is circumstantial evidence that Neolithic cereal and pulse cultivation was intensive (Halstead $1989 a$; for more direct evidence from other regions, see Jones 1992; Bogaard this volume). Such intensive cultivation, especially if closely integrated with the rearing of livestock, should theoretically have been capable of high yields per unit area (cf. Bogaard this volume) and, given sufficient labour (see below), significant levels of overproduction. In practice, as has been argued elsewhere, the early sum- mer harvest of cereals and pulses will have been subject to significant fluctuations in yields, as a result of variable growing conditions, forcing cultivators dependent on such crops into regular overproduction and the generation of a 'normal surplus' ( $\mathrm{Al}$ lan 1965; Forbes 1982; Halstead 1989b). In sum, unless the foregoing arguments as to the size and permanence of Neolithic village communities and their primary dependence on grain crops are radically wrong, periodic agricultural surpluses sufficient to finance large-scale feasting will have been endemic to the Neolithic of Greece.

Turning to the clarity of distinction between host/ provider and guest/consumer, rights to consumption are not easily recognised in the archaeological record, but claims to such rights are often exercised through the spatial organisation of residence and so are amenable to archaeological investigation. For example, in the ethnographic record, non-storing foragers live at higher residential densities than storing hunters or farmers (Fletcher 1981): in the former case, close proximity helps peer pressure to enforce sharing; in the latter case, wider spacing reduces such pressure and facilitates hoarding (cf. Whitelaw 1983). Habitation density is difficult to assess archaeologically, but a striking characteristic of Neolithic material culture in Greece and adjacent regions is architectural and symbolic emphasis on 'houses' (Hodder 1990; Kotsakis 1999). Whether or not such structures are seen as representing the emergence of some form of 'family household', they imply segregation of small residential units. Associated facilities suggest circumscription of activities that included at least some storage and cooking of food (Hourmouziadis 1979; Halstead 1995; 1999), while the elaboration of 'domestic' material culture ( $c f$. Hodder 1990) may indicate that this social fragmentation was contentious. Similar arguments have been advanced on comparable empirical grounds for early farming communities in other regions (Flannery 1972; Wright 2000). There is thus at least circumstantial evidence that early farming communities in Greece met both of Hayden's preconditions for dynamic commensal politics: periodic overproduction of staple grains was almost certainly endemic, while food was arguably private property at least to the extent that any ethos of collective rights to consumption was constrained and contested by domestic architecture and portable material culture.

The existence of periodic agricultural surpluses does not, of course, mean that such surpluses necessarily had to be used to finance feasting. Among general- 
ized foragers, the egalitarian ethos of sharing, especially of large carcasses, is at least reinforced by practical considerations: if meat given away would otherwise have spoiled, the hunter's generosity costs nothing; and, given the relative rarity with which large animals tend to be killed, even the most successful hunter stands some chance of benefitting from a future reciprocal act of generosity. Among storing hunters and farmers, however, surpluses tend to comprise foods that have been, or could be, preserved for future consumption; in such cases, given some uncertainty as to future returns from hunting or farming and some variability in the 'shelf-life' of stores, it is far harder for the prospective host to be sure that generosity is cost-free - that food given away would not otherwise have been consumed before it spoiled. The generous host thus risks either running out of stored food or incurring unnecessary future labour costs in food procurement and processing for storage. Admittedly, work may be regarded as a virtue (e.g., Malinowski 1921). In societies dependent on bulk storage of seasonal abundance, however, the need for human labour can be subject to sharp peaks and additional demands on labour during peak periods may pose a threat to survival, rather than merely eating into leisure time. It is argued below that this will have been the case for Neolithic communities in Greece.

The potential costs and risks of giving away stored food are integrally bound up with the limited collective rights to consumption found in the ethnographic record of societies dependent on storage. Not only does restriction of collective rights to consumption facilitate hoarding and storage, but the linkage between generosity and indebtedness increases the likelihood that the opportunity costs of giving away surplus food will, sooner or later, be balanced by tangible benefits. Again, the new conditional ethos must be sought rather indirectly in the archaeological record. First, the widespread emphasis, in the early Neolithic record of Greece and adjacent regions, on production of ceramic 'tableware' suggests that particular importance was attached to cooked (as opposed to raw) food. Indeed, many of the shapes, decorative motifs and forming techniques of the early Neolithic ceramic repertoire mimic wooden or basketry prototypes (Childe 1957; Tomkins 2001) and it is possible that the initial proliferation of ceramic tableware was due not to any functional superiority of fired clay, but to the symbolic homology between firing and cooking. Either way, the high cultural value placed on cooked food is at least compatible with its being subject to greater obligations of collective enjoyment than was raw food. Such a contrast between raw/private and cooked/public, widely encountered in the ethnographic record (e.g., Sahlins 1974.125-126) and even in modern western society, helps to mediate the contradiction between obligations to share food and rights to accumulate stores. Secondly, if Neolithic 'domestic' architecture arguably served to identify a small group of co-residents with unconditional rights to consumption of stored food, the variable location of cooking facilities both indoors and outdoors suggests some flexibility as to the social distance over which rights to commensality were recognised (Halstead 1995). As in modern European society, the boundaries of commensality were probably extended on 'special' occasions and the frequent co-existence of elaborately decorated and plain, but functionally comparable, ceramic vessels may well reflect the attribution of greater or lesser social significance to different consumption events.

If rights to commensality in the Neolithic were indeed conditional and flexible, is there any evidence that hospitality was reciprocated? In the ethnographic record, hospitality is commonly reciprocated in kind or with labour, and both forms are at least compatible with the archaeological record from the Neolithic of Greece. First, ceramic tableware exhibits similar shapes and decorative styles over substantial distances in space $(\leq 50-75 \mathrm{~km})$ and time (several decades to a few centuries) (e.g., Washburn 1983; Cullen 1984; Rondiri 1985). Such far-flung and longlasting committment to a shared material culture of commensality might, in a more obviously hierarchical social context, be interpreted in terms of regional emulation of a notably generous elite (cf. Wright in press), but is more plausibly comprehended here in terms of webs of reciprocal hospitality. Secondly, if Neolithic domestic architecture does represent something like a household, it will have defined a group that shared obligations of labour as well as rights of consumption ( $c f$. Sahlins 1974). In this context, the flexible social boundaries, implied by the existence of external as well as internal hearths, may well reflect collaboration as much as commensality between neighbours and kin. Similarly, by joining the workforce of a household, distant kin or even non-kin may have gained access to hospitality on which they would otherwise have had no claim. Thus, on a range of social scales, hospitality may have been reciprocated both in kind and with labour, the former representing interaction between social equals and the latter something closer to a patron-client relationship (cf. Dietler, Herbich 2001). 
The dynamic behind both types of relationship may be better understood by considering the risks faced by early farmers in Greece and the probable buffering strategies adopted to mitigate these risks. In effect, it will be argued that routine practices of early farmers in this region not only made feasting possible, but strongly disposed it to become an important arena of social competition.

\section{AGRIQLTURAL RISK AND RISK-BUFFERING: THE IMPORTANCE OF HUMAN LABOUR}

For early farmers in Greece, supplies of staple grain crops will inevitably have been at risk to natural hazards at four successive stages (Forbes 1982; Halstead 1990):

(1) unfavourable weather in autumn-early winter might result in crops being sown on an insufficient scale or on inadequately prepared ground;

(2) unfavourable weather or crop pests during winter and spring might harm or, occasionally, even destroy growing crops;

3 ripe crops in early summer might be decimated in the field by birds or spoiled during threshing by a sudden storm;

4 at any point in the year, stored grain might be lost to insect pests or damp (as well as cultural hazards such as fire or theft).

At the first and third of these stages, in particular, the impact of natural hazards might be mitigated or magnified by an abundance or scarcity, respectively, of human labour. For recent non-mechanised farmers in Greece, the autumn-winter period of tillage and sowing and, even more so, the early summer harvesting and processing period for staple grain crops placed major strain on human labour (Halstead, Jones 1989), to the extent that either unfavourable weather conditions or a reduced workforce might result in the partial, inadequate or delayed completion of tasks. In such a seasonal environment, even delayed completion of some tasks carried serious risks: for example, late sowing makes crop yields less reliable - as the modern Greek saying goes, 'the early-sown crop is blessed by God, the late-sown crop by fortune'. Moreover, for Neolithic farmers, the demands on human labour during tillage may have been significantly higher, if little or no use was made of plough-animals (cf. Sherratt 1981). Thus, any loss of human labour (or increased demands on labour) during the autumn-winter or early summer peak periods of agricultural activity could have dangerously exacerbated the risks to crop production posed by natural hazards.
In combination, these hazards will have constituted a serious threat to survival and, in response, early farmers will almost certainly have deployed a range of buffering strategies:

(1) Diversification The role of crop diversification in cushioning the effects of growing-season hazards has been discussed at length elsewhere (Forbes 1976; 1982; 1989; Halstead 1990) and there is some evidence that Neolithic farmers in Greece did indeed grow a range of cereal and pulse crops ( $\mathrm{Hal}$ stead 1992a). Growing a range of crops may also have extended the sowing and harvesting seasons and so helped to ease the pressures on human labour in autumn-early winter and early summer. On the other hand, there is surprisingly little evidence for foraging at early farming villages in Greece (e.g., Halstead 1999), although a potentially important contribution of domestic animals to subsistence diversification is discussed below.

(2) Overproduction and storage As was noted above, regular overproduction of grain may reasonably be regarded as an essential element of grainbased subsistence in strongly seasonal environments. Overproduction also increases stress on the human workforce during the autumn-early winter and early summer peaks of labour input, however, and so may be unachievable if key tasks are curtailed by unfavourable weather. Partly for this reason, overproduction may be insufficient to cushion farmers against a run of bad years. Ironically, a run of good years might also cause problems: if farmers' estimates of the level of overproduction required for security were determined by both traditional norms ('grandfather responses' - Forbes 1989) and personal experience, repeated failure to consume costly surpluses is likely to have led to less cautious behaviour.

3 Exchange One means of extending the 'shelf-life' of surpluses is to give them away in the expectation of future reciprocation. Although food may be exchanged for valuables, especially between distant social contacts and in circumstances of extreme scarcity (O'Shea 1981), reciprocation in kind and reciprocation with labour are more commonplace and possible evidence for both from the Neolithic of Greece has already been noted. The implications of, and interplay between, reciprocation in kind and with labour are of particular interest in the present context.

Clearly, shortage of labour at crucial points in the agricultural year could restrict the scale and compromise the reliability of grain production and could also undermine attempts to enhance subsistence se- 
curity through overproduction. Conversely, access to additional labour at the same crucial points in the year could boost overproduction and enhance subsistence security.

In the Neolithic, as in the recent past, neighbours and kin probably provided mutual assistance, to the benefit of both parties, in laborious tasks such as field clearance. Reciprocal hospitality too doubtless played an important, and often mutually beneficial, role in initiating or affirming social (as opposed to anti-social) relations within and between Neolithic communities. Exchanges of labour for food at times of peak agricultural activity, however, will have promoted social inequality. Households with disposable surplus will have been able to acquire additional labour and so to minimise the risk that future overproduction be jeopardised by time stress during the critical sowing and harvesting periods; the use of surplus food to secure additional labour will also have reduced the risk that overproduction might come to be regarded, after a run of good years, as an unjustified burden. Conversely, households forced to export labour will have been more likely to fall foul of unfavourable weather during sowing or harvesting and so to end up underproducing. The clear implication of this self-reinforcing assymetry is that the giving away of food may have been especially advantageous if at least some of the recipients were unable to reciprocate in kind. One means of achieving this end may have been to escalate the cost of hospitality, by sponsoring large-scale feasts or serving 'party food' (e.g., beer or meat rather than staples such as bread or gruel). The following section considers the possible significance of domestic animals in such competitive commensality. At this juncture, however, it should be noted that, in the Neolithic of Greece, feasting may not only have been predicated on the existence of surplus, but may equally have justified and facilitated the production of surplus. Moreover, feasting may have been so integrally bound up with the risk-buffering strategies of early farmers that it was as essential to their economic viability as to social reproduction.

\section{LIVESTOCK, MEAT AND FEASTING}

Domestic animals doubtless played a variety of roles in Neolithic farming. They were a source of food, perhaps including milk (e.g., Rowley-Conwy 2000) and blood as well as meat, and also provided raw materials, including hides, hair, horn and bone. Their manure probably boosted crop yields, while their contribution to clearance (cf. Rowley-Conwy 1981) and possible use as pack- or plough-animals ( $c f$. Sherratt 1981) may have helped farmers to make the most of favourable weather at sowing and harvest times. In the event of scarcity of staple grains, fattened livestock may have been a vital alternative source of sustenance, while the feeding of unwanted or spoiled grain to livestock (e.g., Robinson, Rasmussen 1989) may have provided a welcome means of 'indirect storage' (cf. Flannery 1969; Halstead 1993). In addition to this wealth of 'practical' uses, livestock may have been valued for less obviously material reasons. First, if surplus grain was fed to domestic animals, then fattened livestock will have been a very visible and immediately intelligible symbol of the wealth of their owner. Secondly, a range of ethnographic and historical evidence suggests that the killing of domestic animals will have been an event of far greater cosmological significance than is a visit to a modern butcher's shop or supermarket (e.g., Burkert 1983); the consumption of meat, therefore, may well have been a profoundly meaningful experience in the Neolithic. Thirdly, since it is unlikely that individual Neolithic households could maintain viable breeding populations of all four common domestic animal species (sheep, pigs, cattle and goats), livestock were almost certainly exchanged between different productive units within, and perhaps between, villages (Halstead 1992b). Given that such exchanges are likely to have reaffirmed or reshaped existing social relationships, it is inherently likely that livestock thus served as a metaphor for Neolithic society (cf. Dahl 1979).

One context in which many of the practical and symbolic values of domestic animals may have been combined is in feasting. Meat is likely to have been esteemed simply because it was less regularly available than foods based on staple grains and, in a physically active population, particular appreciation of animal fat is likely to have been dictated by human biology, if not also by cultural values. In addition, the killing of domestic animals may have been regarded as a sacrificial act, leading to conspicuous consumption of something that simultaneously represented accumulated wealth and perhaps a particular nexus of social relationships. The meat of domestic animals would thus have been a highly valued form of 'party food' and so an important ingredient in competitive feasting. Were domestic animals consumed in such commensal contexts in the Neolithic of Greece?

Circumstantial evidence in this direction comes from consideration of the practicalities of consuming domestic animals. Whereas most plant foods can be 
prepared for consumption in quantities appropriate to an individual consumer, a family household or a community-wide feast, an animal cannot be slaughtered piecemeal. In recent Greek rural communities, prior to the widespread availability of refrigerators, a family household might eat a chicken or a suckling lamb or kid, but an older lamb or kid would usually be shared with neighbours and a yearling of the same species was likely to be slaughtered for an extended social gathering such as a wedding. An adult sheep might be consumed at a wedding, or preserved and stored for domestic consumption over a period of months; a yearling or older pig similarly tended to be preserved and stored. A steer might be slaughtered for a village-wide festival, but most cattle were sold in urban markets.

Much of this oral history refers to the mid-twentieth century, when rural households were often large and carcass weights of livestock often low. Surviving and recovered faunal remains from Neolithic villages in Greece indicate high levels of later first- and second-year slaughter of pigs; high levels of later first- and second-year and also older slaughter in sheep and goats; and perhaps even older average age of slaughter in rather poor samples of cattle (Halstead in prep.). Thus almost all the available evidence for slaughter of domestic animals is derived from animals too big to have been consumed fresh by a single household, even if these were rather more extended than their recent counterparts. There is little if any hint in Neolithic mortality data that age of slaughter was heavily shaped by the desire for secondary products (milk, wool or traction). On the contrary, the high proportions of older juveniles, subadults and young adults represented are suggestive rather of emphasis on the raising of large carcasses for consumption. It might be argued that many of these animal carcasses were preserved for long-term domestic consumption, but in the recent past slaughter for storage typically took place in the cold winter months to minimise the risk of meat spoiling while being salted, smoked or sealed in fat. Available mortality data suggest that slaughter was more or less staggered through the year (Halstead in press), implying that many carcasses were consumed fresh. Finally, studies of butchery traces offer no hint of a high level of wastage of carcasses (Pappa et al. in press; Isaakidou 2004).

In sum, it is likely that many, perhaps most, of the domestic animals slaughtered at Neolithic villages were consumed by a social group larger, and often much larger, than the household. Moreover, a high proportion of these animals could have been slaughtered at a substantially younger age, without any loss of secondary products, and could then plausibly have been consumed by a smaller social group without sharing with outsiders. The implication is that these animals were not merely consumed at large-scale feasts, but were reared for this purpose. As in recent rural society, the slaughter of cattle will have been appropriate for especially large commensal occasions, perhaps marking particularly important points in the life-cycle of a household or larger social group. This may be one source of the apparently exceptional cultural value of cattle in Neolithic society, implied by their dominance in the repertoire of zoomorphic figurines (Toufexis 2003).

\section{CONQLUSION: THE POLITICAL ECOLOGY OF FEASTING IN THE NEOLITHIC OF GREECE}

It has been argued here that feasting, in the sense of commensality on a social scale larger than the basic unit of agricultural producers, was an important practice in the Neolithic of Greece. This claim finds some empirical support in the Neolithic material culture of Greece, in which decorated ceramic 'tableware' is prominent. Attempts to model society and economy in the Neolithic of Greece suggest that feasting will have served, inter alia, to mobilise additional agricultural labour, to negotiate and affirm social relationships at both an intra- and inter-settlement level, and to convert agricultural surpluses into symbolic capital in the context of social competition. All of these roles are well exemplified in ethnographic accounts of feasting in recent horticultural societies (e.g., Richards 1939; Allan 1965; Dietler 2001; Dietler, Herbich 2001; Hayden 2001a).

It has also been argued that the large size of many or most of the domestic animal carcasses represented on Neolithic settlements in Greece implies consumption in the context of large-scale commensality. Most of these domestic animals could have been slaughtered at a younger age, at a carcass size appropriate to consumption by a much smaller social unit, equivalent perhaps to a 'household' group of producers. In this respect, it might be argued that domestic animals in the Neolithic of Greece were raised for consumption in feasting - again a suggestion that has already been made for other cultural contexts (e.g., Keswani 1994; Hayden 2001b).

As Dietler and Hayden have recently emphasised (Dietler, Hayden 2001), feasting is a very wide- 
spread phenomenon, takes a great variety of forms in different cultural contexts, and has significant potential to generate social change. This paper has attempted to develop this last point by exploring the ecological context of competitive commensality. Dietler and Hayden draw attention to some fundamental paradigmatic divergences between those, such as Dietler, who see feasting primarily as a competitive political activity, and others, including Hayden, who emphasise the 'practical' benefits of feasting. As Dietler and Hayden acknowledge, however, there is room for manouevre between these perspectives and this paper seeks to exploit this potential rather than to endorse either paradigmatic pole.

The starting point for this attempt is the observation that feasting expends substantial surpluses and that such surpluses are often accumulated as a risk-buffering measure in societies dependent on storage and living in environments characterised by marked seasonality and inter-annual variability. In such contexts, food production, and even more so overproduction, tends to place significant strain on human labour resources, to the extent that the expenditure of unused food surpluses to mobilise additional labour may significantly enhance survival prospects as well as leisure time. In a highly seasonal environment, where the scheduling of tasks may be both tightly constrained and critical to their success, reciprocal exchanges of labour may reduce the drudgery of agricultural labour. The acquisition of human labour in return for surplus food, however, is highly beneficial to the 'host' and potentially disastrous for the 'guest'. Moreover, the transition from egalitarian reciprocal hospitality to inegalitarian exchange of food for labour may have been subject to few cultural constraints, precisely because such patronage can be construed as no more than the welcoming of an additional member to the household.

In this context, conspicuous feasting may play an important 'economic' role both in driving less successful households into indebtedness and subservience and in enabling successful farmers to compete with each other for the position of preeminent host and labour-beneficiary. Feasting is thus enabled by, but also helps to promote and perpetuate, overproduction. In this respect, competitive feasting could be regarded as a political strategy for promoting subsistence security. Whether the goal of overproduction and feasting, as perceived by the Neolithic inhabitants of Greece, was subsistence security or political advantage is arguably unimportant and certainly unknowable. In this ecological context, however, not only does overproduction have the potential to enhance subsistence security and enable feasting, but the hosting of feasts can justify and facilitate overproduction and subsistence security.

I am grateful to Miha Budja, for the invitation to par-
ticipate in a most enjoyable and productive meeting,
and to the University of Sheffield, for contributing to
the costs of attendance. I am also indebted to Amy
Bogaard and Valasia Isaakidou, for comments on
this paper, and to Kostas Kotsakis, Maria Pappa, Dus-
ka Urem-Kotsou and Valasia Isaakidou for discus-
sions, while working on the Makriyalos and Paliam-
bela projects, of food consumption in the Neolithic.

\section{REFERENCES}

ALLAN W. 1965. The African Husbandman. Edinburgh. Oliver and Boyd.

ANDREOU S., FOTIADIS M., KOTSAKIS K. 1996. Review of Aegean prehistory 5: the Neolithic and Bronze Age of northern Greece. American Journal of Archaeology 100: 537-597.

BARNARD A., WOODBURN J. 1991. Property, power and ideology in hunting and gathering societies: an introduction. In T. Ingold, D. Riches and J. Woodburn (eds.), Hunters and Gatherers, 2: Property, Power and Ideology: 4-31.
BOTTEMA S. 1982. Palynological investigations in Greece with special reference to pollen as an indicator of human activity. Palaeohistoria 24: 257-289.

BROWN P. 1978. Highland Peoples of New Guinea. Cambridge. Cambridge University Press.

BURKERT W. 1983. Homo necans: the Anthropology of Ancient Greek Sacrificial Ritual and Myth. Berkeley. University of California Press.

CHAGNON N. A. 1968. Yanomamo: the Fierce People. New York. Holt, Rinehart and Winston. 
CHILDE V. G. 1957. The Dawn of European Civilisation. London. Routledge and Kegan Paul.

CULLEN T. 1984. Social implications of ceramic style in the Neolithic Peloponnese. In W. D. Kingery (ed.), Ancient Technology to Modern Science, volume 1: $77-100$.

DAHL G. 1979. Ecology and equality: the Boran case. In Pastoral Production and Society: 261-281.

DIETLER M. 2001. Theorizing the feast: rituals of consumption, commensal politics, and power in African contexts. In M. Dietler and B. Hayden (eds.), Feasts: Archaeological and Ethnographic Perspectives on Food, Politics and Power: 65-114.

DIETLER M., HAYDEN B. 2001. Digesting the feast: good to eat, good to drink, good to think. In M. Dietler and B. Hayden (eds.), Feasts: Archaeological and Ethnographic Perspectives on Food, Politics and Power: 1-20.

DIETLER M., HERBICH I. 2001. Feasts and labor mobilization. In M. Dietler and B. Hayden (eds.), Feasts: Archaeological and Ethnographic Perspectives on Food, Politics and Power: 240-264.

FLANNERY K. V. 1969. Origins and ecological effects of early Near Eastern domestication. In P. J. Ucko and G. W. Dimbleby (eds.), The Domestication and Exploitation of Plants and Animals: 73-100.

1972. The origins of the village as a settlement type in Mesoamerica and the Near East: a comparative study. In P. J. Ucko, R. Tringham and G. W. Dimbleby (eds.), Man, Settlement and Urbanism: 23-53.

FLETCHER R. 1981. People and space: a case study on material behaviour. In I. Hodder, G. Isaac and N. Hammond (eds.), Pattern of the Past: Studies in Honour of David Clarke: 97-128.

FORBES H. 1976. 'We have a little of everything': the ecological basis of some agricultural practices in Methana, Trizinia. Annals of the New York Academy of Sciences 268: 236-250.

1982. Strategies and Soils: Technology, Production and Environment in the Peninsula of Methana, Greece. PhD dissertation. University of Pennsylvania.
1989. Of grandfathers and grand theories: the hierarchised ordering of responses to hazard in a Greek rural community. In P. Halstead and J. O'Shea (eds.), Bad Year Economics: 87-97.

FORGE A. 1972. Normative factors in the settlement size of neolithic cultivators (New Guinea). In P. J. Ucko, R. Tringham and G. W. Dimbleby (eds.), Man, Settlement and Urbanism: 363-376.

HALSTEAD P. 1989a. Like rising damp? An ecological approach to the spread of farming in southeast and central Europe. In A. Milles, D. Williams and N. Gardner (eds.), The Beginnings of Agriculture (BAR International Series 496): 23-53.

1989b. The economy has a normal surplus: economic stability and social change among early farming communities of Thessaly, Greece. In P. Halstead and J. 0. 'Shea (eds.), Bad Year Economics: 68-80.

1990. Waste not, want not: traditional responses to crop failure in Greece. Rural History 1: 147164.

1992a. Agriculture in the Bronze Age Aegean: towards a model of palatial economy. In B. Wells (ed.), Agriculture in Ancient Greece: 105-116.

$1992 b$. From reciprocity to redistribution: modelling the exchange of livestock in Neolithic Greece. Anthropozoologica 16: 19-30.

1993. Banking on livestock: indirect storage in Greek agriculture. Bulletin on Sumerian Agriculture 7: 63-75.

1995. From sharing to hoarding: the neolithic foundations of Aegean Bronze Age society? In R. Laffineur and W.-D. Niemeier (eds.), Politeia: Society and State in the Aegean Bronze Age (Aegaeum 12): 11-20.

1999. Neighbours from hell: the household in Neolithic Greece. In P. Halstead (ed.), Neolithic Society in Greece: 77-95.

in press. Resettling the Neolithic: faunal evidence for seasons of consumption and residence at Neolithic sites in Greece. In D. Bailey and A. Whittle (eds.), Unsettling the Neolithic. 
HALSTEAD P., JONES G. 1989. Agrarian ecology in the Greek islands: time stress, scale and risk. Journal of Hellenic Studies 109: 41-55.

HAYDEN B. 2001a. Fabulous feasts: a prolegomenon to the importance of feasting. In M. Dietler and B. Hayden (eds.), Feasts: Archaeological and Ethnographic Perspectives on Food, Politics and Power: 23-64.

2001b. The dynamics of wealth and poverty in the transegalitarian societies of southeast Asia. Antiquity 75: 571-581.

HITSIOU E. 2003. Production and Circulation of the Late Neolithic Pottery from Makrygialos (Phase II), Macedonia, Northern Greece. PhD dissertation. University of Sheffield.

HODDER I. 1990. The Domestication of Europe. 0xford. Blackwell.

HOURMOUZIADIS G. 1979. To Neolithiko Dimini. Volos. Society for Thessalian Studies.

INGOLD T. 1980. Hunters, Pastoralists and Ranchers: Reindeer Economies and their Transformations. Cambridge. Cambridge University Press.

1983. The significance of storage in hunting societies. Man 18: 553-571.

1986. The Appropriation of Nature: Essays on Human Ecology and Social Relations. Manchester. Manchester University Press.

ISAAKIDOU V. 2004. Bones from the Labyrinth: Faunal Evidence for the Management and Consumption of Animals at Neolithic and Bronze Age Knossos, Crete. $\mathrm{PhD}$ dissertation. University College London.

JONES G. 1992. Weed phytosociology and crop husbandry: identifying a contrast between ancient and modern practice. Review of Palaeobotany and Palynology 73: 133-143.

KENT S. 1993. Variability in faunal assemblages: the influence of hunting skill, sharing, dogs, and mode of cooking on faunal remains at a sedentary Kalahari community. Journal of Anthropological Archaeo$\log y$ 12: 323-385.
KESWANI P. 1994. The social context of animal husbandry in early agricultural societies. Journal of Anthropological Archaeology 13: 255-277.

KOTSAKIS K. 1982. Recent research at Sesklo. In Symposia Thracica 1982: 265-269.

1999. What tells can tell: social space and settlement in the Greek Neolithic. In P. Halstead (ed.), Neolithic Society in Greece: 66-76.

MALINOWSKI B. 1922. Argonauts of the Western Pacific. London. Routledge.

MAUSS M. 1970. The Gift. London. Routledge and Kegan Paul.

O'SHEA J. 1981. Coping with scarcity: exchange and social storage. In A. Sheridan and G. Bailey (eds.), Economic Archaeology (BAR International Series 96): $167-183$.

PAPPA M., HALSTEAD P., KOTSAKIS K., UREM-KOTSOU D. in press. Evidence for large-scale feasting at Late Neolithic Makriyalos, N Greece. In P. Halstead and J. Barrett (eds.), Food, Cuisine and Society in Prehistoric Greece.

PERLÈS C. 1999. The distribution of magoules in eastern Thessaly. In P. Halstead (ed.), Neolithic Society in Greece: $42-56$.

RAPPAPORT R. A. 1968. Pigs for the Ancestors. London. Yale University Press.

RICHARDS A. I. 1939. Land, Labour and Diet in Northern Rhodesia. Oxford. Oxford University Press.

ROBINSON D., RASMUSSEN P. 1989. Leaf hay and cereals as animal fodder. In A. Milles, D. Williams and N. Gardner (eds.), The Beginnings of Agriculture (BAR International Series 496): 149-163.

RONDIRI V. 1985. Epifaniaki keramiki neolithikon theseon tis Thessalias: katanomi sto khoro. Anthropologika 8: 53-74.

ROWLEY-CONWY P. 1981. Slash and burn in the temperate European Neolithic. In R. J. Mercer (ed.), Farming Practice in British Prehistory: 85-96.

2000. Milking caprines, hunting pigs: the Neolithic economy of Arene Candide in its West Medi- 
terranean context. In P. Rowley-Conwy (ed.), Animal Bones, Human Societies: 124-132.

SAHLINS M. 1974. Stone Age Economics. London. Tavistock Publications.

SHERRATT A. 1981. Plough and pastoralism: aspects of the secondary products revolution. In I. Hodder, G. Isaac and N. Hammond (eds.), Pattern of the Past: Studies in Honour of David Clarke: 261-305.

1991. Palaeoethnobotany: from crops to cuisine. In F. Queiroga and A. P. Dinis (eds.), Paleoecologia e Arqueologia 2: 221-36.

THEOCHARIS D. R. 1980. To neolithiko spiti. Anthropologika 1: 12-14.

TOMKINS P. 2001. The Production, Circulation and Consumption of Ceramic Vessels at Early Neolithic Knossos, Crete. PhD dissertation. University of Sheffield.

TOMKINS P., DAY P. 2001. Production and exchange of the earliest ceramic vessels in the Aegean: a view from Early Neolithic Knossos, Crete. Antiquity 75: 259-260.

TOUFEXIS G. 2003. Animals in the Neolithic art of Thessaly. In E. Kotjabopoulou, Y. Hamilakis, P. Halstead, C. Gamble and P. Elefanti (eds.), Zooarchaeology in Greece: Recent Advances: 263-271.

VITELLI K. D. 1989. Were pots first made for food? Doubts from Franchthi. World Archaeology 21: 1729.
WASHBURN D. K. 1983. Symmetry analysis of ceramic design: two tests of the method on neolithic material from Greece and the Aegean. In D. K. Washburn (ed.), Structure and Cognition in Art: 138164.

WHITELAW T. M. 1983. People and space in huntergatherer camps: a generalising approach in ethnoarchaeology. Archaeological Review from Cambridge 2: 48-66.

WHITTLE A. 1997. Moving on and moving around: neolithic settlement mobility. In P. Topping (ed.), Neolithic Landscapes: 15-22.

WIESSNER P. 2001. Of feasting and value: Enga feasts in a historical perspective (Papua New Guinea). In M. Dietler and B. Hayden (eds.), Feasts: Archaeological and Ethnographic Perspectives on Food, Politics and Power: 115-143.

WILLIS K. J., BENNETT K. D. 1994. The neolithic transition fact or fiction? Palaeoecological evidence from the Balkans. The Holocene 4: 326-330.

WRIGHT J. in press. Mycenaean drinking services and standards of etiquette. In P. Halstead and J. Barrett (eds.), Food, Cuisine and Society in Prehistoric Greece.

WRIGHT K. 2000. The social origins of cooking and dining in early villages of western Asia. Proceedings of the Prehistoric Society 66: 89-121. 